\title{
Ecotoxicological assessment of water and sediment of the Corumbataí River, SP, Brazil
}

\author{
Jardim, GM.*, Armas, ED. and Monteiro, RTR. \\ Laboratório de Ecotoxicologia, Centro de Energia Nuclear na Agricultura, \\ Universidade de São Paulo - USP, Av. Centenário, 303, CEP 13416-000, Piracicaba, SP, Brazil \\ *e-mail: cgjardim@techs.com.br \\ Received March 16, 2006 - Accepted March 19, 2007 - Distributed February 29, 2008
}

(With 6 figures)

\begin{abstract}
The Corumbataí River drains an economically important area which is mainly represented by the municipalities of Piracicaba and Rio Claro. In view of the impacts caused by the discharge of industrial waste and domestic sewage into the Piracicaba River, the Corumbataí has become increasingly significant as a source of water for the municipality of Piracicaba. However, chemical, physical, and microbiological analyses carried out prior to the present study had already indicated a decline in the quality of the Corumbataí waters. This study aimed to assess, through water and sediment samples, both acute and chronic toxicity to Daphnia magna and Daphnia similis, and to analyze acidvolatile sulfide (AVS) and simultaneously extracted metal (SEM) in the sediment. Resulting data were intended to be a contribution to future projects for the management and recuperation of this system. To that aim, water and sediment were collected at seven Corumbataí sampling stations in November 2003 and March 2004. Acute toxicity to D. similis was detected in water and sediment samples from the Piracicaba station, located at the mouth of the Corumbataí River. Chronic toxicity was identified in the water or sediment samples of all stations, with the exception of Analândia Montante (upstream), at the head of the river. This was found to affect survival, growth, and fecundity of the testorganisms. The AVS and SEM analyses showed the bioavailability of the metals, thus explaining toxicity found in bioassaying samples of water and sediment. The use of two test-organism species made it possible to obtain a better assessment of the condition of both water and sediment samples of the Corumbataí River.
\end{abstract}

Keywords: toxicity, sediment, Corumbataí River, metals.

\section{Avaliação ecotoxicológica da água e do sedimento do rio Corumbataí, SP}

\section{Resumo}

O rio Corumbataí drena uma área de importância econômica representada principalmente pelos municípios de Piracicaba e Rio Claro. Face aos impactos causados pelos lançamentos de efluentes industriais e domésticos no rio Piracicaba, o rio Corumbataí assumiu importância para o abastecimento do município de Piracicaba. Entretanto, análises químicas, físicas e microbiológicas realizadas no rio Corumbataí anteriormente a este estudo, indicaram a queda da qualidade de suas águas. Os objetivos deste estudo foram a avaliação da toxicidade aguda e da toxicidade crônica das amostras de água e sedimento, para Daphnia magna e Daphnia similis, e a análise do sulfeto volatilizável por acidificação (SVA) e dos metais simultaneamente extraídos do sedimento (MSE), no sentido de fornecer dados que possam contribuir com projetos futuros de manejo e recuperação desse sistema. Para tanto, água e sedimento provenientes de sete estações de coleta do rio Corumbataí foram coletados em novembro de 2003 e março de 2004. Foi detectada toxicidade aguda para $D$. similis das amostras de água e sedimento da estação Piracicaba, na foz do rio Corumbataí. A toxicidade crônica foi identificada na água ou no sedimento de todas as estações de coleta, exceto Analândia Montante (nascente do rio), influenciando a sobrevivência, crescimento e fecundidade dos organismos-teste. As análises do SVA e MSE revelaram a biodisponibilidade dos metais, explicando a toxicidade das amostras de água e de sedimento encontrada nos bioensaios. A adoção de duas espécies de organismos-teste possibilitou uma melhor avaliação dos compartimentos amostrados.

Palavras-chave: toxicidade, sedimento, rio Corumbataí, metais. 


\section{Introduction}

The Corumbataí River basin, which drains an area of $1,679 \mathrm{~km}$, is located in São Paulo State, Brazil, between latitude $22^{\circ} 05^{\prime}-22^{\circ} 30^{\prime} \mathrm{S}$, and longitude $47^{\circ} 30^{\prime}-47^{\circ} 50^{\prime} \mathrm{W}$. The river itself, which is located on the northeastern edge of the Paraná Sedimentary Basin in a cuesta zone of São Paulo State's Peripheral Depression, drains an area of economic and industrial growth with a population estimated at 550,871 (IBGE, 2001). The Corumbataí runs through the municipalities of Analândia, Corumbataí, and Rio Claro, and flows into the Piracicaba River. Together with the basins of the rivers Atibaia and Jaguari, the Corumbataí River basin is part of the Piracicaba River basin. Physical, chemical, and microbiological monitored parameters have demonstrated the reduction in water and sediment quality related to the high raw sewage remaining discharge (SEMA, 2005). According to the Environmental Sanitation Technology Company (CETESB), the municipalities together generate approximately 44 tons of BOD per day, of which only 10.9 tons are treated. Throughout the river course, industrial activity is concentrated in Rio Claro, and is represented by chemical, metallurgical, electronic, food, and beverage industries. At the mouth of the river, it is represented by sugar and alcohol production activities. Even though industrial waste has been reduced, the remaining daily discharge still corresponds to that produced by a population of 244,000 inhabitants (Salati, 1996). The occurrence of mineral resources favors clay and sand mining, the excavations cause alterations in the river, and there is lack of adequate management to reduce the impacts (Palma-Silva, 1999). Studies have demonstrated the influence of laminar erosion in the relation between dissolved phosphate in the river's water and the use of fertilizers by regional sugar and alcohol industries (Conceição and Bonotto, 2000). Other studies carried out in the Corumbataí River indicate runoff as the source of compounds released in limestone mining or associated with sugarcane cultivation (see Conceição and Bonotto, 2004).

Sediment is a dynamic component of a hydrographic basin, and creates habitats favorable to biodiversity; but it also acts as a source of contamination through the release of compounds into the water, which justifies the investigation of its toxicity. Toxicity tests are fundamental when one seeks the protection of the organisms in the ecosystems. In the case of the Corumbataí River, sediment toxicity at a sampling point was previously identified by Costa and Espíndola (2002). In the present study, toxicity tests were carried out in order to identify water and sediment toxicity in samples taken from seven sampling points in the Corumbataí River.

Studies of elutriate toxicity have demonstrated that this exposure route must also be investigated ( $\mathrm{Li} \beta$ and Ahlf, 1997). In the present work, acute and chronic toxicity tests were conducted, taking into account that concentrations which are not toxic within 48 hours can be so within a longer exposure period, thus acting on other life-cycle stages of the organism. Given that toxic activity is affected by biological diversity, two species were used as test-organisms: Daphnia magna Straus and Daphnia similis Straus. D. magna species is USEPArecommended (2002), whereas in Brazil D. similis has been used by CETESB in toxicity tests since 1986 (CETESB, 1987).

Sulfide and metal concentrations in the sediments can be used to predict metal bioavailability and toxicity in samples. According to Di Toro et al. (1992), sediment sulfides easily combine with bivalent metal ions, thus forming insoluble precipitates. Analyses of acidvolatile sulfide (AVS) and simultaneously extracted metals (SEM) indicate metal bioavailability when the metal/ sulfide ratio is greater than one. Investigations about the usefulness of the acid extraction of the sulfide and the simultaneously extracted metals have confirmed the prediction of toxicity of the sample when the metal/sulfide ratio exceeds one; inversely, non-toxic samples are observed when there is excess of sulfide (see Hansen et al., 1996). In this study, analyses of molar concentrations of sulfide and metals in sediment were carried out in order to observe metal bioavailability in the system and its effects in toxicity tests.

The contribution of this study is the confirmation of the existence of pollutants in the system of the Corumbataí River. Although these pollutants have already been observed by other researchers (Palma-Silva, 1999; Salati, 1996), the present study adds the ecotoxicological assessment of this river's water and sediment. The importance of this assessment is the determination of the sample's toxicity to the biotic systems, and not only of its chemical composition. These conclusions agree with those of Adams (1995), who affirmed that neither physical nor chemical analyses can measure toxicity, but only predict it. In addition, the results of this study indicate the presence of bioavailable metals as one of the possible causes of the toxicity observed.

\section{Material and Methods}

\subsection{Samplings}

Two samplings of water and sediment were done at seven points located up-and downstream from sewage discharge areas in four municipalities (Figure 1). Each point was designated by municipality and position initials - upstream (u) or downstream (d) relative to sewage discharge area: Analândia ( $\mathrm{Au}$ and $\mathrm{Ad})$, Corumbataí ( $\mathrm{Cu}$ e $\mathrm{Cd})$, Rio Claro ( $\mathrm{RCu}$ e $\mathrm{RCd}$ ), and Piracicaba (Pira, in the mouth of the Corumbataí River). Samplings occurred in November 2003 and March 2004. Sediments were collected using a longhandled perforated stainless steel container, following which each sample was placed in a plastic bag, which was then sealed. Superficial water was collected using a stainless steel container and stored in polyethylene flasks. Water and sediment were stored at $4{ }^{\circ} \mathrm{C}$ until initiating ecotoxicological assays. 


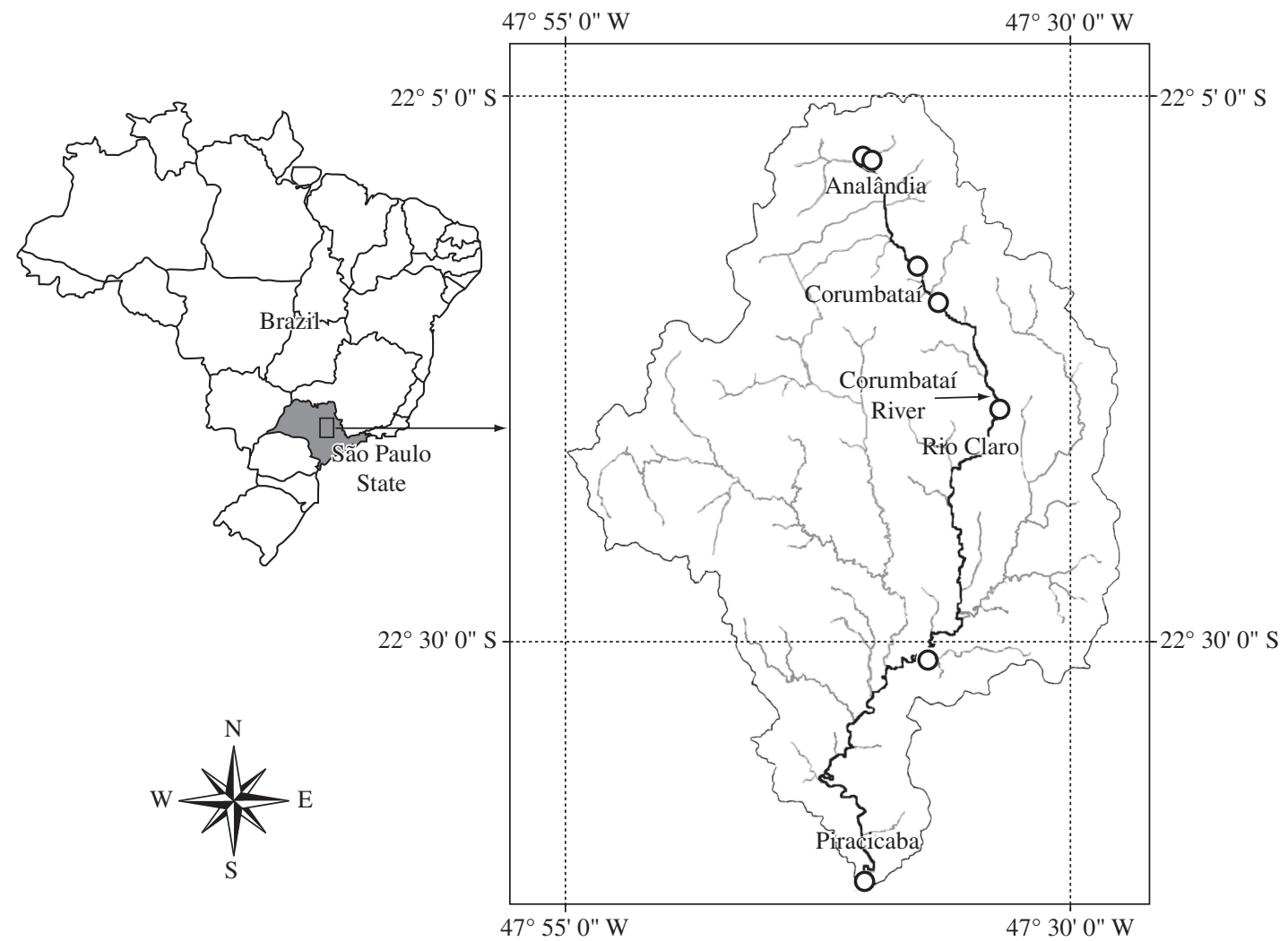

Figure 1. Corumbataí River from headwaters until the mouth of the Piracicaba River; sampling points ( O ).

\subsection{Culture and ecotoxicological assays}

Organism culture and ecotoxicological assay procedures followed the norms established by ABNT, the Brazilian Association for Technical Norms (2003b, NBR 13373). Cultures were kept in the Ecotoxicology and Culture Laboratory of the Ecology and Evolutionary Biology Department of the Federal University of São Carlos (UFSCAR). Measurements of $\mathrm{pH}$ and hardness were made during the ecotoxicological assays, and at their end. The following criteria were adopted for assessing acute toxicity: toxic samples were defined as those which caused immobility of $40 \%$ or above of test-organisms; non-toxic samples indicated immobility not exceeding $10 \%$; immobility rates ranging between 10-40\% indicate samples with signs of toxicity.

\subsection{Statistical analysis}

To evaluate organism reaction both in samples and the control, the Tukey (parametric) and Kruskall-Wallis (nonparametric) tests were applied at a $5 \%$ probability level, using the software SAS 6.11.

\subsection{Acid-volatile sulfide and simultaneously extracted metals}

The procedure used in the acid extraction of the sulfide and metals from the sediment followed Allen et al. (1993) and was carried out in the Environmental Biogeochemistry Laboratory of UFSCAR's Chemistry Department. Quantification of $\mathrm{Cu}, \mathrm{Zn}, \mathrm{Cr}, \mathrm{Cd}$, and $\mathrm{Pb}$ metals was done in the Analytical Chemistry Laboratory of the Center for Nuclear Energy in Agriculture (CENA) of the University of São Paulo, and employed inductively coupled plasma atomic emission spectrometry, as well as graphite-furnace atomic absorption spectrometry.

\subsection{Sensitivity tests}

Sensitivity tests were made in accordance with ABNT norms (2003b, NBR 13373) to evaluate testorganism physiological conditions, using potassium dichromate as the reference substance. Median effective concentration (EC50) was calculated by the Trimmed Spearman-Karber method (Hamilton et al., 1977).

\subsection{Acute toxicity tests on water samples}

Duration of acute toxicity tests was 48 hours. Culture water served as the control. Immobile organisms were counted at the conclusion of the ecotoxicological assays. The organisms were first exposed to undiluted water from the sampling points. Five neonates that were at most 48 hours old were used, and three replicas were made. 


\subsection{Acute toxicity tests on sediment samples}

A ratio of 1:4 sediment/dilution water was used in the acute toxicity tests, following Burton and MacPherson (1995). After 24 hours five organisms were placed in the container, and three replicas were made. Culture water was used as the control. In the experiment with elutriate the same sediment/water ratio was used, and after being agitated for 24 hours, the supernatant was used in the toxicity tests, following SETAC (1993). Toxicity tests lasted 48 hours.

\subsection{Chronic toxicity tests on sediment samples}

The ratio of sediment to dilution water used was the same as that used for acute toxicity tests. One neonate was introduced into each container, and 10 replicas were made. The toxicity test was ended as soon as $60 \%$ of the control organisms produced the third brood of young, following Burton and MacPherson (1995). The containers were kept at approximately $23{ }^{\circ} \mathrm{C}$, with a 12 hours photoperiod. Neonates and adult immobile organisms were counted every two days. Neonates were removed, water was changed, and remaining organisms were fed daily. At the conclusion of the experiment, the organisms were measured with a Wild stereomicroscope.

\subsection{Chronic toxicity tests on water samples}

Ecotoxicological assays on water samples followed the same methodology as that used for chronic toxicity on sediment. Due to problems with the samples, the test was interrupted after seven days.

\section{Results}

In Table 1, the concentrations of acid-volatile sulfide and simultaneously extracted metals are expressed in $\mu \mathrm{mol} / \mathrm{g}$ of dried sediment. They indicate metal excess in the metal/sulfide ratio and also toxicity prediction, thus showing $\mathrm{RCu}$ and Pira as the most contaminated locations, with the potential for causing reductions in survival, fecundity, and growth of the test-organisms. They also show a less endangered location, Au. In November, $\mathrm{Cu}$ station presented the greatest $\mathrm{Cu}$ concentrations (Figure 2) in relation to sulfite. $\mathrm{RCu}$ station presented the greatest $\mathrm{Zn}$ and $\mathrm{Cr}$ concentrations (Figures 3 and 4) in relation to sulfite. In March, $\mathrm{Cu}$ and Ad locations presented the highest $\mathrm{Cu}$ and $\mathrm{Zn}$ concentrations, respectively. The highest chromium content were found in Pira and RCd stations, while $\mathrm{Cd}$ and $\mathrm{Pb}$ concentrations were higher in RCd (Figures 5 and 6). The sediment contamination by metals is indicated by the results presented here, a fact that is confirmed by high metal concentration data obtained by CETESB (2003, 2004, and 2005) in the Corumbataí River water analyses.

The sampling points proved toxic to D. magna and D. similis. Both water and sediment samples from Pira station demonstrated toxicity in all experiments made. In sensitivity tests, the lesser EC50 value for $D$. similis demonstrates this organism's greater sensitivity when compared with that of D. magna (Table 2).

Table 3 indicates signs of acute toxicity in water samples for D. magna and D. similis and toxicity at Pira station to D. similis. In the chronic toxicity tests with water samples, D. similis proved more sensitive than D. magna.

Acute toxicity of the sediment of November 2003 was also detected in Pira station to D. similis (Table 4), causing an immobility rate of $100 \%$, while in the next

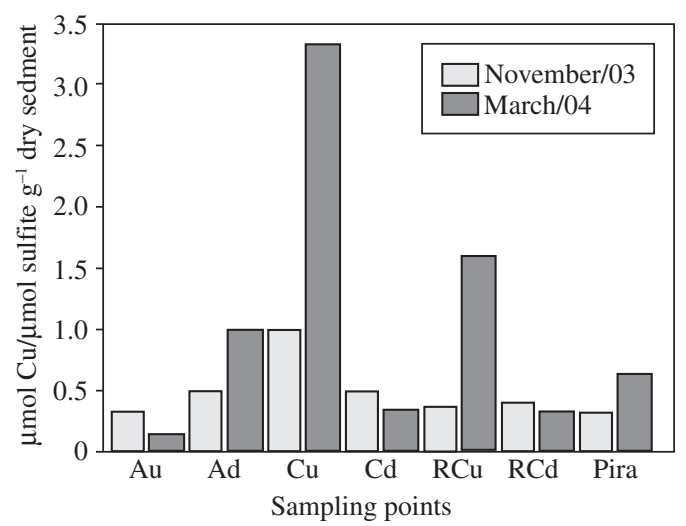

Figure 2. $\mathrm{Cu}$ /sulfide ratio per gram of dry sediment; samples from points along the Corumbataí River, Brazil, in November 2003 and March 2004.

Table 1. Whole metal and sulfide concentrations and metal/sulfide (Me/S) ratio found in November (Nov) and March (Mar) sediment samples, and predictions yielded by ecotoxicological assessments. Au: Analândia upstream; Ad: Analândia downstream; Cu: Corumbataí upstream; Cd: Corumbataí downstream; $\mathrm{RCu}$ : Rio Claro upstream; RCd: Rio Claro downstream, and Pira: Piracicaba.

\begin{tabular}{|c|c|c|c|c|c|c|c|}
\hline \multirow[t]{2}{*}{ Sampling points } & \multicolumn{2}{|c|}{$\Sigma$ metals $\left(\mu\right.$ mol.g $\left.^{-1}\right)$} & \multicolumn{2}{|c|}{ Sulfide $\left(\mu\right.$ mol.g$\left.^{-1}\right)$} & \multicolumn{2}{|c|}{ Metal/sulfide } & \multirow{2}{*}{$\begin{array}{c}\text { Toxicity } \\
\text { prediction }\end{array}$} \\
\hline & Nov & Mar & Nov & Mar & Nov & Mar & \\
\hline $\mathrm{Au}$ & 0.114 & 0.042 & 0.03 & 0.03 & 3.8 & 1.4 & Toxic \\
\hline $\mathrm{Ad}$ & 0.115 & 0.197 & 0.02 & 0.02 & 5.7 & 9.8 & Toxic \\
\hline $\mathrm{Cu}$ & 0.05 & 0.128 & 0.01 & 0.02 & 5.0 & 6.4 & Toxic \\
\hline $\mathrm{Cd}$ & 0.04 & 0.075 & 0.02 & 0.02 & 2.0 & 3.7 & Toxic \\
\hline $\mathrm{RCu}$ & 0.35 & 0.076 & 0.03 & 0.02 & 11.6 & 3.8 & Toxic \\
\hline $\mathrm{RCd}$ & 0.1 & 0.088 & 0.05 & 0.02 & 2.0 & 4.4 & Toxic \\
\hline Pira & 0.52 & 0.285 & 0.25 & 0.02 & 2.1 & 14.2 & Toxic \\
\hline
\end{tabular}




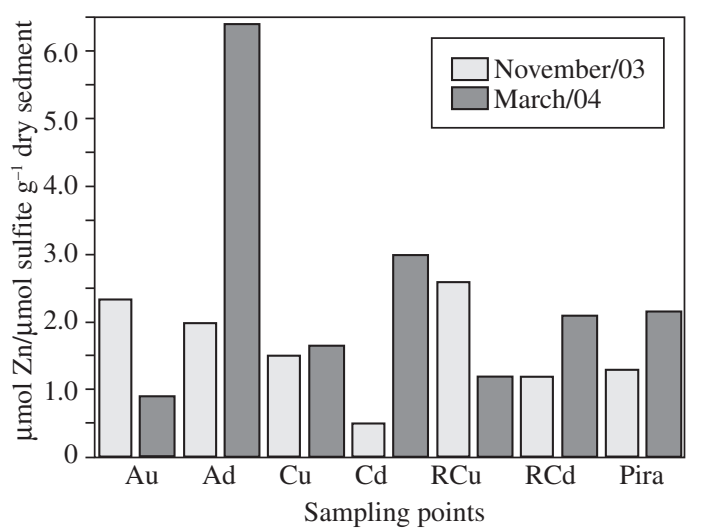

Figure 3. $\mathrm{Zn}$ /sulfide ratio per gram of dry sediment; samples from points along the Corumbataí River, Brazil, in November 2003 and March 2004.

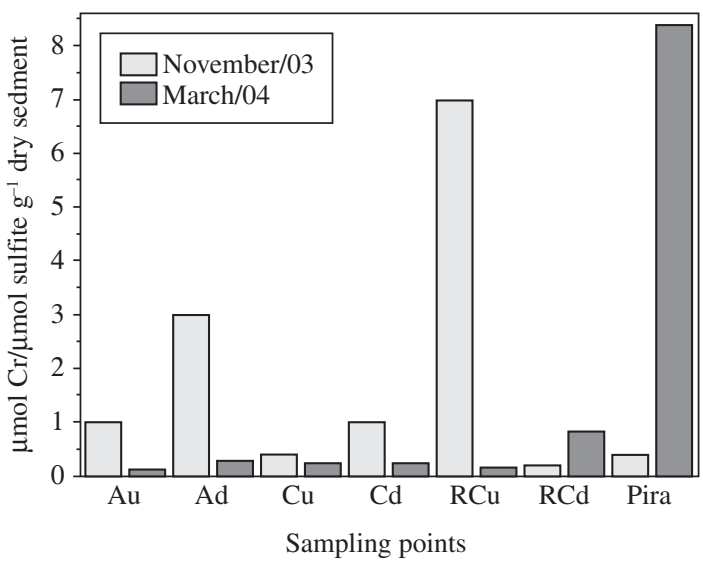

Figure 4. Cr/sulfide ratio per gram of dry sediment; samples from points along the Corumbataí River, Brazil, in November 2003 and March 2004.

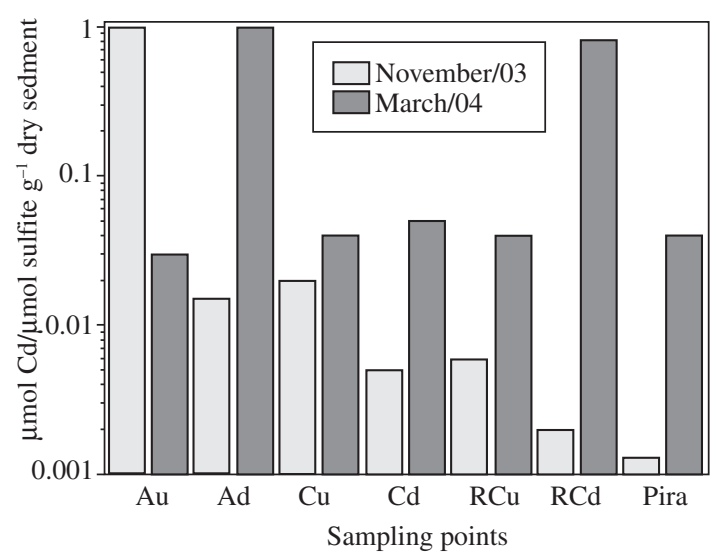

Figure 5. Cd/sulfide ratio per gram of dry sediment; samples from points along the Corumbataí River, Brazil, in November 2003 and March 2004.

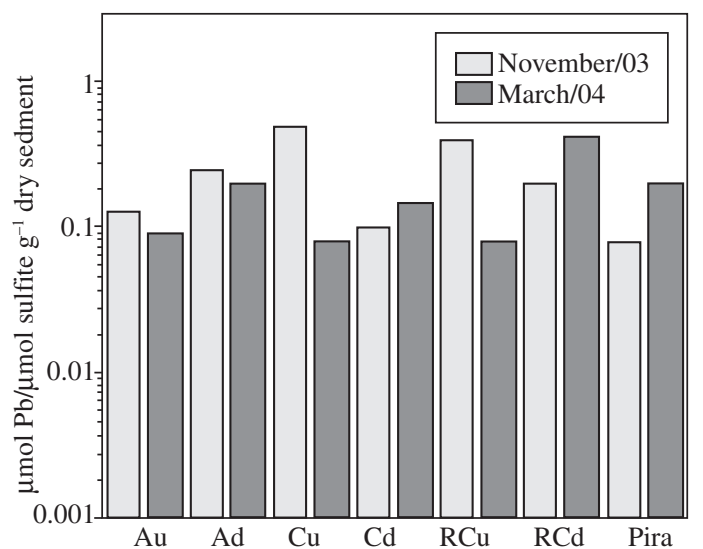

Figure 6. $\mathrm{Pb} / \mathrm{sulfide}$ ratio per gram of dry sediment; samples from points along the Corumbataí River, Brazil, in November 2003 and March 2004.

sampling there were signs of toxicity in most of the sampling points to D. magna.

In ecotoxicological assays on elutriate, immobility of $D$. similis was greater than that observed in whole sediment; in addition, the ecotoxicological assays showed a greater number of locations with signs of toxicity. To D. magna all points excepting Au presented toxicity signs. Results are shown in Table 5.

Chronic toxicity in the sediments from $\mathrm{Ad}, \mathrm{RCu}$, $\mathrm{RCd}$, and Pira stations was proven, with $D$. similis presenting a greater rate of immobility than D. magna (Table 6). Chronic effects on growth and fecundity were observed in all sampling points, except $\mathrm{Cu}$, thus suggesting that the sediment in these locations is potentially toxic to these test-organisms. Comparisons with the control shown in Table 7 indicate that sensitivity to sediment samples was greater in D. similis than in D. magna.

\subsection{Chemical and physical variables}

Hardness detected in the samples indicated low salts content, and no great modification was observed during the toxicity tests. The lowest $\mathrm{pH}$ found was 7.1, considered normal in continental waters (Esteves, 1998).

\section{Discussion}

Microcrustaceans of the Daphnia genus are frequently used in assays testing acute and chronic toxicity, due to their sensitivity to many aquatic contaminants and easy maintenance in laboratory cultures. Daphnids ingest sediment and are consumed by numerous fish species. For ecotoxicological assays in very hard waters, $D$. magna is especially recommended. In Brazil, CETESB has introduced the use of $D$. similis as test-organism in ecotoxicological assays, whose procedures have already been standardized (ABNT, 2003a, NBR 12713).

Since sensitivity varies according to the toxic agent and environmental conditions, use of more than one species may be helpful in ecotoxicological assays. For example, 
Table 2. Values of EC50 and confidence limit of monthly sensitivity tests using potassium dichromate of D. magna and D. similis.

\begin{tabular}{|c|c|c|c|c|}
\hline \multirow[t]{2}{*}{ Date } & \multicolumn{2}{|r|}{ D. magna } & \multicolumn{2}{|r|}{ D. similis } \\
\hline & $\operatorname{EC50}\left(\mathrm{mg}^{2} \mathrm{~L}^{-1}\right)$ & Confidence limit (mg.L $\left.{ }^{-1}\right)$ & $\operatorname{EC50}\left(\mathrm{mg}^{\prime} \mathrm{L}^{-1}\right)$ & Confidence limit (mg. $\left.\mathrm{L}^{-1}\right)$ \\
\hline November & 0.20 & $0.17-0.24$ & 0.03 & $0.02-0.04$ \\
\hline March & 0.14 & $0.11-0.18$ & 0.04 & $0.04-0.06$ \\
\hline
\end{tabular}

Table 3. Immobility percentage of D. magna and $D$. similis in ecotoxicological assays of chronic and acute toxicity of water from sampling points in the Corumbataí River in November; $\mathrm{pH}$ and water hardness at the conclusion of the assays; Ac: acute and Chr: chronic.

\begin{tabular}{|c|c|c|c|c|c|c|c|c|c|c|c|c|}
\hline \multirow{3}{*}{$\begin{array}{c}\text { Sampling } \\
\text { points }\end{array}$} & \multicolumn{6}{|c|}{ D. magna } & \multicolumn{6}{|c|}{ D. similis } \\
\hline & \multicolumn{2}{|c|}{$\begin{array}{c}\text { Immobility } \\
(\%)\end{array}$} & \multicolumn{2}{|c|}{$\begin{array}{c}\text { Hardness } \\
\text { mg.L }^{-1} \\
\mathrm{CaCO}_{3} \\
\end{array}$} & \multicolumn{2}{|c|}{$\mathbf{p H}$} & \multicolumn{2}{|c|}{$\begin{array}{c}\text { Immobility } \\
(\%)\end{array}$} & \multicolumn{2}{|c|}{$\begin{array}{c}\text { Hardness } \\
\text { mg.L }^{-1} \\
\mathrm{CaCO}_{3} \\
\end{array}$} & \multicolumn{2}{|c|}{ pH } \\
\hline & Ac & Chr & Ac & Chr & Ac & Chr & Ac & Chr & Ac & Chr & Ac & Chr \\
\hline Control & 0 & 0 & 193 & 186 & 7.9 & 8.4 & 0 & 0 & 48 & 74 & 7.5 & 7.8 \\
\hline $\mathrm{Au}$ & 0 & 10 & 16 & 22 & 7.3 & 7.2 & 13.3 & 10 & 22 & 18 & 7.4 & 7.5 \\
\hline $\mathrm{Ad}$ & 26.6 & 10 & 79 & 79 & 7.5 & 7.5 & 26.6 & 40 & 80 & 78 & 7.3 & 7.3 \\
\hline $\mathrm{Cu}$ & 0 & 10 & 49 & 53 & 7.2 & 7.8 & 13.3 & 30 & 48 & 49 & 7.4 & 7.3 \\
\hline $\mathrm{Cd}$ & 6.6 & 0 & 92 & 86 & 7.4 & 7.5 & 20 & 40 & 89 & 89 & 7.5 & 7.5 \\
\hline $\mathrm{RCu}$ & 13.3 & - & 36 & - & 8.1 & - & 13.3 & - & 31 & - & 7.5 & - \\
\hline $\mathrm{RCd}$ & 0 & - & 27 & - & 7.2 & - & 0 & - & 26 & - & 7.5 & - \\
\hline Pira & 0 & 0 & 44 & 42 & 7.6 & 7.4 & 40 & - & 43 & - & 7.5 & - \\
\hline
\end{tabular}

Table 4. Immobility percentages of D. magna and D. similis in ecotoxicological assessment of acute toxicity of sediment from sampling points in the Corumbataí River in November (Nov) and March (Mar); pH and water hardness at the conclusion of the assays.

\begin{tabular}{|c|c|c|c|c|c|c|c|c|c|c|c|}
\hline \multirow{3}{*}{ Sampling points } & \multicolumn{5}{|c|}{ D. magna } & \multicolumn{6}{|c|}{ D. similis } \\
\hline & \multicolumn{2}{|c|}{$\begin{array}{c}\text { Immobility } \\
(\%)\end{array}$} & \multirow{2}{*}{$\begin{array}{c}\begin{array}{c}\text { Hardness } \\
\text { mg.L }^{-1} \\
\mathrm{CaCO}_{3}\end{array} \\
\text { Nov }\end{array}$} & \multicolumn{2}{|c|}{ pH } & \multicolumn{2}{|c|}{$\begin{array}{c}\text { Immobility } \\
(\%)\end{array}$} & \multicolumn{2}{|c|}{$\begin{array}{c}\text { Hardness } \\
\text { mg.L }^{-1} \\
\mathrm{CaCO}_{3}\end{array}$} & \multicolumn{2}{|c|}{ pH } \\
\hline & Nov & Mar & & Nov & Mar & Nov & Mar & Nov & Mar & Nov & Mar \\
\hline Control & 0 & 6.7 & 204 & 8.1 & 8.0 & 0 & 0 & 44 & 74 & 7.6 & 7.3 \\
\hline $\mathrm{Au}$ & 0 & 6.7 & 180 & 7.8 & 8.1 & 0 & 0 & 44 & - & 7.6 & 7.5 \\
\hline $\mathrm{Ad}$ & 0 & 20 & 193 & 8.2 & 7.9 & 0 & 0 & 44 & 80 & 7.6 & 7.2 \\
\hline $\mathrm{Cu}$ & 13.3 & 6.7 & 170 & 8.1 & 8.0 & 0 & 0 & 44 & 56 & 7.6 & 7.3 \\
\hline $\mathrm{Cd}$ & 0 & 33.4 & 210 & 7.8 & 7.9 & 13.3 & 13.3 & 44 & 72 & 7.6 & 7.6 \\
\hline $\mathrm{RCu}$ & 13.3 & 33.4 & 195 & 7.4 & 7.8 & 0 & 13.3 & 44 & 56 & 7.6 & 6.9 \\
\hline $\mathrm{RCd}$ & 6.6 & 20 & 183 & 7.8 & 7.9 & 6.7 & 6.7 & 44 & 48 & 7.6 & 7.0 \\
\hline Pira & 13.3 & 26.7 & 210 & 8.2 & 8.0 & 100 & 13.3 & 44 & 54 & 7.6 & 7.0 \\
\hline
\end{tabular}

we observed that, in spite of the results obtained in testing sensitivity to potassium dichromate, D. magna presented a sensitivity which was either equal to or greater than that of D. similis in certain samples. Indeed, in toxicity tests with metals, Buratini et al. (2004) have found a great correlation between the EC50 values for both species.

The Pira sampling site, which is located near the mouth of the river and has high concentration of industries, presented the worst conditions of water and sediment quality in the tests for acute toxicity to $D$. similis in November. The water samplings collected in November produced chronic effects in the majority of places where signs of acute toxicity were detected, indicating the presence of toxic agents whose action was accentuated by prolonged periods of exposure. The most degraded sediments, which were collected in March, resulted in more numerous incidents of chronic toxicity, causing high immobility and significant size and fecundity alterations. The effects on fecundity were more evident in the three sampling stations which are nearest to the mouth of the river. Therefore, the toxicity that was observed points towards anthropic impacts 
Table 5. Immobility percentages of D. magna and D. similis in ecotoxicological assessment of acute toxicity of elutriate in March from sampling points in the Corumbataí River; $\mathrm{pH}$ and water hardness at the conclusion of the assays.

\begin{tabular}{lccccc}
\hline Sampling points & \multicolumn{2}{c}{ D. magna } & \multicolumn{3}{c}{ D. similis } \\
\cline { 2 - 5 } & $\begin{array}{c}\text { Immobility } \\
(\%)\end{array}$ & $\mathbf{p H}$ & $\begin{array}{c}\text { Immobility } \\
(\boldsymbol{\%})\end{array}$ & $\begin{array}{c}\text { Hardness } \\
\text { mg.L.-1 }_{\mathbf{C a C O}^{-1}}\end{array}$ & $\mathbf{p H}$ \\
\hline Control & 0 & 7.5 & 6.6 & 49 & 7.8 \\
$\mathrm{Au}$ & 0 & 7.6 & 0 & 24 & 7.5 \\
$\mathrm{Ad}$ & 13.3 & 7.5 & 13.3 & 30 & 7.3 \\
$\mathrm{Cu}$ & 13.3 & 7.7 & 0 & 42 & 7.3 \\
$\mathrm{Cd}$ & 20 & 7.3 & 26.6 & 40 & 7.2 \\
$\mathrm{RCu}$ & 26.6 & 7.5 & 26.6 & 45 & 7.6 \\
$\mathrm{RCd}$ & 20 & 7.5 & 20 & 36 & 7.4 \\
Pira & 20 & 7.4 & 20 & 28 & 7.2 \\
\hline
\end{tabular}

Table 6. Immobility percentages of D. magna and D. similis in ecotoxicological assessment of chronic toxicity of sediment in November (Nov) and March (Mar) from sampling points in the Corumbataí River; $\mathrm{pH}$ and water hardness at the conclusion of the assays.

\begin{tabular}{|c|c|c|c|c|c|c|c|c|c|c|c|c|}
\hline \multirow{3}{*}{$\begin{array}{l}\text { Sampling } \\
\text { points }\end{array}$} & \multicolumn{6}{|c|}{ D. magna } & \multicolumn{6}{|c|}{ D. similis } \\
\hline & \multicolumn{2}{|c|}{$\begin{array}{c}\text { Immobility } \\
(\%)\end{array}$} & \multicolumn{2}{|c|}{$\begin{array}{c}\text { Hardness } \\
\text { mg.L }^{-1} \\
\mathrm{CaCO}_{3}\end{array}$} & \multicolumn{2}{|c|}{ pH } & \multicolumn{2}{|c|}{$\begin{array}{c}\text { Immobility } \\
(\%)\end{array}$} & \multicolumn{2}{|c|}{$\begin{array}{c}\text { Hardness } \\
\text { mg.L }^{-1} \\
\mathrm{CaCO}_{3}\end{array}$} & \multicolumn{2}{|c|}{ pH } \\
\hline & Nov & Mar & Nov & Mar & Nov & Mar & Nov & Mar & Nov & Mar & Nov & Mar \\
\hline Control & 0 & 0 & 178 & 162 & 7.9 & 8.1 & 0 & 10 & 44 & 38 & 7.4 & 7.5 \\
\hline $\mathrm{Au}$ & 30 & 20 & 180 & 134 & 8.2 & 8.0 & 20 & 30 & 44 & 42 & 7.4 & 7.5 \\
\hline $\mathrm{Ad}$ & 10 & 30 & 188 & 128 & 8.1 & 8.1 & 30 & 50 & 44 & 36 & 7.4 & 7.2 \\
\hline $\mathrm{Cu}$ & 10 & 0 & 166 & 133 & 8.2 & 8.1 & 20 & 10 & 44 & 46 & 7.4 & 7.4 \\
\hline $\mathrm{Cd}$ & 0 & 20 & 160 & 114 & 8.2 & 8.1 & 20 & 20 & 44 & 44 & 7.4 & 7.5 \\
\hline $\mathrm{RCu}$ & 0 & 60 & 156 & 159 & 8.0 & 8.0 & 40 & 50 & 44 & 38 & 7.4 & 7.6 \\
\hline $\mathrm{RCd}$ & 20 & 30 & 184 & 160 & 8.0 & 8.0 & 10 & 60 & 44 & 50 & 7.4 & 7.4 \\
\hline Pira & 0 & 30 & 158 & - & 8.1 & 8.0 & - & 70 & - & 56 & - & 7.5 \\
\hline
\end{tabular}

Table 7. Fecundity and mean body size \pm standard deviation of D. magna and D. similis in ecotoxicological assessment of chronic toxicity of sediment from sampling points in the Corumbataí River in November (Nov) and March (Mar).

\begin{tabular}{|c|c|c|c|c|c|c|c|c|}
\hline \multirow[t]{3}{*}{ Sampling points } & \multicolumn{4}{|c|}{$\begin{array}{l}\text { D. magna } \\
\text { D.similis }\end{array}$} & \multicolumn{4}{|c|}{ D. similis } \\
\hline & \multicolumn{2}{|c|}{$\begin{array}{l}\text { Num. of } \\
\text { neonates }\end{array}$} & \multicolumn{2}{|c|}{$\begin{array}{c}\text { Mean size } \\
(\mathbf{m m})\end{array}$} & \multicolumn{2}{|c|}{$\begin{array}{l}\text { Num. of } \\
\text { neonatos }\end{array}$} & \multicolumn{2}{|c|}{$\begin{array}{c}\text { Mean size } \\
(\mathrm{mm})\end{array}$} \\
\hline & Nov & Mar & Nov & Mar & Nov & Mar & Nov & Mar \\
\hline Control & 159 & 111 & $1.87 \pm 0.001$ & $2.09 \pm 0.17$ & 327 & 232 & $1.39 \pm 0.14$ & $1.86 \pm 0.08$ \\
\hline $\mathrm{Au}$ & 277 & 80 & $1.79 \pm 0.07$ & $1.89 \pm 0.04$ & 214 & 104 & $1.35 \pm 0.11$ & $1.76 \pm 0.09$ \\
\hline $\mathrm{Ad}$ & 185 & 75 & $1.69 \pm 0.28$ & $1.86 \pm 0.16$ & 106 & 65 & $1.19 \pm 0.04$ & $1.69 \pm 0.09$ \\
\hline $\mathrm{Cu}$ & 225 & 94 & $1.81 \pm 0.16$ & $1.9 \pm 0.18$ & 184 & 182 & $1.32 \pm 0.08$ & $1.82 \pm 0.09$ \\
\hline $\mathrm{Cd}$ & 211 & 126 & $1.88 \pm 0.24$ & $1.85 \pm 0.14$ & 245 & 97 & $1.32 \pm 0.07$ & $1.71 \pm 0.15$ \\
\hline $\mathrm{RCu}$ & 147 & 31 & $1.87 \pm 0.18$ & $1.59 \pm 0.09$ & 128 & 38 & $1.20 \pm 0.04$ & $1.56 \pm 0.05$ \\
\hline $\mathrm{RCd}$ & 240 & 53 & $1.76 \pm 0.11$ & $1.79 \pm 0.06$ & 264 & 31 & $1.38 \pm 0.06$ & $1.61 \pm 0.12$ \\
\hline Pira & 194 & 50 & $1.78 \pm 1.75$ & $1.78 \pm 0.094$ & - & 82 & - & $1.66 \pm 0.05$ \\
\hline
\end{tabular}

Values in bold indicate a statistically significant difference between the samples and the control. 
caused not only by raw sewage but also industrial waste discharged into the river.

Literature data on D. magna's sensitivity to copper and to chrome show EC50 values varying from 0.11 to $1.1 \mu \mathrm{mol} . \mathrm{L}^{-1}$ and from 0.38 to $6.7 \mu \mathrm{mol} . \mathrm{L}^{-1}$, respectively (Bulus Rossini and Ronco, 1996); D. magna's fecundity is reduced at $1.26 \mu \mathrm{mol} . \mathrm{L}^{-1}$ of copper (Winner and Farrell, 1976). The chronic effects of copper on the growth of $D$. magna's body have been observed at $0.4 \mu \mathrm{mol} . \mathrm{L}^{-1}$ (Koivisto et al., 1992). To copper sulphide, zinc sulphide and potassium dichromate, the EC50 values for $D$. similis were, respectively, $3.3 \mu \mathrm{mol} . \mathrm{L}^{-1}$, $37.2 \mu \mathrm{mol} . \mathrm{L}^{-1}$ and $4.5 \mu \mathrm{mol} . \mathrm{L}^{-1}$; the EC50 of potassium dichromate for D. magna was $3.7 \mu \mathrm{mol}^{-L^{-1}}$ (Buratini et al., 2004). Lead chronic toxicity for D. magna is found in the range of $0.05 \mu \mathrm{mol} . \mathrm{L}^{-1}$ to $0.2 \mu \mathrm{mol} . \mathrm{L}^{-1}$ (Borgman et al., 1978), while acute toxicity is observed at $2.17 \mu \mathrm{mol} . \mathrm{L}^{-1}$ (Biesinger and Christensen, 1972). In relation to cadmium, EC50 for D. magna is $0.11 \mu \mathrm{mol} . \mathrm{L}^{-1}$ (USEPA, 2001); D. magna's fecundity is affected at $0.001 \mu \mathrm{mol} . \mathrm{L}^{-1}$ of cadmium (Biesinger and Christensen, 1972). Such data demonstrate that the quantities of bioavailable metals found in the sediments of the Corumbataí River would be enough to cause acute and chronic toxicity to $D$. similis and D. magna.

The sediment was more damaging than the water to the test organisms. Developed to evaluate sediment effects on water quality (Ingersoll, 1995), the ecotoxicological assays with elutriate done in this work confirmed the toxic potential of the river's sediment, thus indicating contaminant release.

The metal bioavailability found in the AVS and SEM analyses of every sampling site coincides with the toxicity found in the samples. These metals are used in mining, foundries, and in food processing, paper, and textile industries (all of which can be easily found in the areas nearby sampling stations RCu, RCd and Pira), accumulate in the sediment and may be released into the water (Forstner, 1983). Acid conditions in the area studied were observed by other authors (see Lara et al, 2001), and can result in considerable ecological damage, for $\mathrm{pH}$ reduction favors metal solubility, thus turning complex ions into free ions, which are generally more toxic to aquatic organisms (Jorgensen, 1993). As for physical and chemical variables, the samples' low degree of hardness confirmed the activity of metal, since its toxicity is reduced in harder waters (Rattner and Health, 1995).

The present results indicate the sediments of the Corumbataí River as a route followed by the pollutants. In order to broaden this river component assessment, it is recommended that further studies are conducted, and, thus, provide the basis for implementing recuperation projects in the area.

Acknowledgments - This study was made possible through financial support of the project entitled "Evaluating Water Quality by Ecotoxicological Assays in the Corumbataí Subbasin" by the Foundation for the Support of Research in the State of São Paulo (FAPESP).

\section{References}

ABNT - ASSOCIAÇÃO BRASILEIRA DE NORMAS TÉCNICAS, 2003a. Ecotoxicologia aquática - toxicidade aguda - método de ensaio com Daphnia spp. (Crustacea, Cladocera). NBR 12713, Rio de Janeiro, Brasil.

-, 2003b. Ecotoxicologia aquática - toxicidade crônica-método de ensaio com Ceriodaphnia spp. (Crustacea, Cladocera). NBR13373, Rio de Janeiro, Brasil.

ADAMS, WJ., 1995. Aquatic toxicology testing methods, p. 25-45. In HOFFMAM, DJ., RATTNER, BA., BURTON GA. and CAIRNS, J. (eds.), Handbook of ecotoxicology. Lewis Publishers, Boca Raton, Florida, 663 p.

ALLEN, HE., FU, G. and DENG, B., 1993. Analysis of acid-volatile (AVS) and simultaneously metals (SEM) for the estimation of potential toxicity in the aquatic sediments, Environmental Toxicology and Chemistry, vol. 12, no. 8, p. 1441-1453.

BIESINGER, KE. and CHRISTENSEN, GM., 1972. Effects of various metals on survival, growth, reproduction and metabolism of Daphnia magna. J. Fish. Res. Board Can. vol. 29, no. 12, p. $1691-1700$.

BULUS ROSSINI, GD. and RONCO, AE., 1996. Acute toxicity bioassay using Daphnia obtusa as a test organism. Environmental Toxicology and Water Quality. vol. 11, no. 3, p. 255-258.

BURATINI, SV., BERTOLETTI, E. and ZAGATTO, PA., 2004. Evaluation of Daphnia similis as a test species in ecotoxicological assays. Bull. Environ. Contam. Toxicol., vol. 73 , no. 5, p. 878-882.

BURTON, GA. and MACPHERSON, C., 1995. Sediment toxicity testing issues and methods, p. 71-103. In HOFFMAM, DJ., RATTNER, BA., BURTON, and CAIRNS, J. (eds.), Handbook of. ecotoxicology. Lewis Publishers, Boca. Raton, Florida, $663 \mathrm{p}$.

CETESB - COMPANHIA DE TECNOLOGIA DE SANEAMENTO AMBIENTAL, 1987. Avaliação da toxicidade de efluentes líquidos de algumas indústrias localizadas na bacia do rio Piracicaba. CETESB, São Paulo, 8 p.

-, 2003. Relatório de qualidade das águas interiores do Estado de São Paulo 2002. Relatórios Ambientais, ISSN 0103-4103, CETESB, São Paulo, 271 p.

-, 2004. Relatório de qualidade das águas interiores do Estado de São Paulo 2003. Relatórios Ambientais, ISSN 0103-4103, CETESB, São Paulo, 278 p.

-, 2005. Relatório de qualidade das águas interiores do Estado de São Paulo 2004. Relatórios Ambientais, ISSN 0103-4103, CETESB, São Paulo, 297 p.

CONCEIÇÃO, FT. and BONOTTO, DM., 2000. Anthropogenic influences on the uranium concentration in waters of the Corumbataí River Basin (SP), Brazil. Revista Brasileira de Geociências, vol. 30, no. 3, p. 551-553.

-, 2004. Weathering rates and anthropogenic influences in a sedimentary basin, São Paulo State, Brazil. Applied Geochemistry, vol. 19, no. 4, p. 575-591.

COSTA, JB. and ESPÍNDOLA, ELG., 2002. Avaliação ecotoxicológica da água e sedimento em tributários do Reservatório de Barra Bonita (Médio Tietê Superior, SP), p. 75-93. In ESPÍNDOLA, ELG., PASCHOAL, CMRB., 
ROCHA, O., Bohrer, MBC. and OLIVEIRA-NETO, AL.(eds), Ecotoxicologia perspectivas para o século XXI. Rima, São Carlos, $575 \mathrm{p}$.

DI TORO, DM., MAHONY, JD., HANSEN, DJ., SCOTT, KJ., CARLSON, AR. and ANKLEY, GT., 1992. Acid volatile sulfide predicts the acute toxicity of cadmium and nickel in sediments. Environmental Science and Technology, vol. 15, no. 12 , p. $2138-2146$.

ESTEVES, FA., 1998. Fundamentos de limnologia. Interciência, Rio de Janeiro, $601 \mathrm{p}$.

FÖRSTNER, U. and WITTMANN, GTW, 1983. Metal pollution in the aquatic environment. Springer-Verlag, New York, 486 p.

HAMILTON, MA., RUSSO, RC. and THURSTON, RV., 1977. Trimmed Spearman-Karber method for estimating median lethal concentrations in toxicity bioassays. Environmental. Science and Technology, vol. 11, no. 7, p. 714-719.

HANSEN, DJ., BERRY, DJ., MAHONY, JD., BOOTHMAN, WS., DI TORO, DM., ROBSON, DL., ANKLEY, GT., MA, D., YAN, Q. and PESCH, CE., 1996. Predicting the toxicity of metal-contamined field sediments using intersticial concentration of metals and acid-volatile sulfide normalizations. Environmental Toxicology and Chemistry, vol. 15, no. 12, p. 2080-2094.

IBGE - INSTITUTO BRASILEIRO DE GEOGRAFIA E ESTATÍSTICA, 2001. Censo demográfico 2000 Características da população e dos domicílios, resultados do universo, p. 313-320. IBGE, Rio de Janeiro, 520 p.

INGERSOLL, CG., 1995. Sediment test, p. 103-131. In RAND, GM. (ed.), Fundamentals of aquatic toxicology: effects, environmental fate, and risk assessment. Taylor and Francis, Washington, $1115 \mathrm{p}$.

JORGENSEN, SE., 1993. Effects of lake acidification, cap.3, p. 47-69. In JORGENSEN, SE. (ed.), Acidification (Guidelines of Lake Management), vol. 5. OTSU, ILEC-UNEP, 195 p. Nairobi.

KOIVISTO, S., KETOLA, M. and WALLS, M., 1992. Comparison of five cladoceran species in short- and long-term copper exposure. Hydrobiologia, vol. 248, no. 2, p. 125-136.

LARA, LBLS., ARTAXO, P., MARTINELLI, LA., VICTORIA, RL., CAMARGO, PB., KRUSHE, A., AYERS, GP., FERRAZ,
ESB. and BALLESTER, MV., 2001. Chemical composition of rainwater and anthropogenic influences in the Piracicaba River Basin, Southeast Brazil. Atmospheric Environment, vol. 35, no. 29 , p. 4937-4945.

LIß, W. and AHLF, W., 1997. Evidence from whole-sediment, porewater, and elutriate testing in toxicity assessment of contamined sediments. Ecotoxicology and Environmental Safety, vol. 36, no. 2, p. 140-147.

PALMA-SILVA, GM., 1999. Diagnóstico ambiental, qualidade da água e índice de depuração do rio Corumbataí-SP. (Dissertação Mestrado) - Universidade Estadual Paulista (UNESP), Rio Claro, 155 p.

RATTNER, BA. and HEALTH, AG., 1995. Environmental factors affecting contaminant toxicity in aquatic and terrestrial vertebrates, p. 519-535. In HOFFMAN, DJ., RATTNER, BA., BURTON GA. and CAIRNS, J. (eds.), Handbook of Ecotoxicology. Lewis Publishers,Boca. Raton, Florida, 663 p.

SALATI, E., 1996. Diagnóstico ambiental sintético e qualidade da água como subsídio para o planejamento regional integrado da bacia hidrográfica do rio Corumbataí (SP). (Tese de Doutorado) - Escola de Engenharia de São Carlos, Universidade de São Paulo, São Carlos, 199 p.

SEMA - SECRETARIA ESTADUAL DO MEIO AMBIENTE, 2005. Relatório de qualidade ambiental do Estado de São Paulo 2004: lei 9509/97. Diário Oficial do Estado de São Paulo, Poder Executivo, Seção I-supl., vol. 115, no. 113, 18/06/05, 48 p.

SETAC - SOCIETY OF ENVIRONMENTAL TOXICOLOGY AND CHEMISTRY, 1993. Guidance document on sediment toxicity tests and bioassays for freshwater and marine environments. In HILL, IR., MATTHIESSEN, P. and HEIMBACH, F. Workshop on sediment toxicity assessment, SETAC, Renesse, The Netherlands, 105 p.

USEPA - UNITED STATES ENVIRONMENTAL AGENCY, 2001. USEPA822-R01-001. Update of ambient water quality criteria for cadmium. Washington, D.C., 166 p.

-, 2002. USEPA/821-R02-012. Methods for measuring the acute toxicity of effluents and receiving waters to freshwaters and marine organisms. $5^{\text {ed }}$. Washington, D.C., 275 p.

WINNER, RW. and FARREL, MP., 1976. Acute and chronic toxicity of copper to four species of Daphnia. J. Fish Res. Board Can. vol. 33, p. 1685-1691. 
